\title{
PRC1 wt Allele
}

National Cancer Institute

\section{Source}

National Cancer Institute. PRC1 wt Allele. NCI Thesaurus. Code C118350.

Human PRC1 wild-type allele is located in the vicinity of 15q26.1 and is approximately 30 $\mathrm{kb}$ in length. This allele, which encodes protein regulator of cytokinesis 1, plays a role in both mitotic spindle integ rity and cytokinesis. 